\title{
Spotkanie kultur - spotkanie gestów. O rozumieniu wybranych brytyjskich gestów emblematycznych przez Polaków uczących się języka angielskiego
}

Zgodnie z danymi Komisji Europejskiej język angielski jest najpopularniejszym językiem obcym nauczanym w Polsce. Z badań wynika, że po angielsku mówi $18 \%$ Polaków, z czego prawie $32 \%$ to ludzie młodzi, między 15 . a 34. rokiem życia ${ }^{1}$. Możliwość swobodnego wyjazdu do krajów anglojęzycznych, także w ramach kursów językowych, powszechność języka angielskiego w internecie, jak również obecność rodzimych użytkowników tego języka w Polsce sprawiają, że Polacy coraz częściej mogą komunikować się m.in. z Brytyjczykami twarzą w twarz oraz obserwować ich zachowania konwersacyjne.

Celem niniejszego tekstu jest przedstawienie zagadnienia dekodowania (poprawnego odczytania/rozumienia) wybranych brytyjskich gestów emblematycznych przez Polaków uczących się języka angielskiego.

Przed przystąpieniem do badań założono, że osoby świadomie uczące się języka angielskiego chcą skutecznie porozumiewać się z użytkownikami tego języka, także z osobami przynależącymi do kręgu kultury brytyjskiej. Do tego potrzebna jest znajomość realiów kulturowych, w tym niewerbalnego wymiaru komunikacji, na który składają się m.in. gesty ${ }^{2}$. Gestami typowymi dla danej kultury są gesty emblematyczne (tzw. emblematy) — znaki arbitralne, o ustalonej

${ }^{1}$ Natomiast $\mathrm{z}$ analiz przeprowadzonych na podstawie Polskiego Sondażu Uprzedzeń 2013 wynika, że 53\% Polaków deklaruje znajomość co najmniej jednego języka obcego, z czego 28\% zna język angielski (za: Hansen, Witkowska 2014, s. 4).

2 Na temat istotności komunikatów niewerbalnych w procesie porozumiewania się (a zwłaszcza w komunikacji twarzą w twarz) pisali m.in.: Birdwhistell, Hall, Ekman i Friesen, Kendon, Morris, Mehrabian, Argyle, Knapp i Hall, Nęcki, Pease, McNeill, Jarząbek, Antas, Załazińska, Leathers i wielu innych (zob. Szczepaniak 2012, s. 471). 
formie, używane świadomie, zastępujące dane słowa i frazy, powszechnie rozumiane przez rodzimych użytkowników języka. Emblematy często mają własną nazwę, bywa znana ich historia użycia (por. Efron 1941/1972; Ekman, Friesen 1969; Ekman 1999; Szczepaniak, Piekot 2009). To pełnowartościowe akty komunikacji, których znajomość może być wyznacznikiem poziomu znajomości języka i kultury. Stąd zasadne zdało się postawienie następujących pytań badawczych: jak ważna jest znajomość realiów kulturowych (w tym niewerbalizmów) dla osób uczących się języków obcych? Czy uczący się języka obcego (tu: angielskiego) znają realia kulturowe danego obszaru językowego? Czy są świadomi istnienia oraz istotności i funkcji niewerbalizmów w procesie komunikacji, ich wpływu na skuteczne i efektywne porozumiewanie się? Wszak podczas komunikowania się wiadomość werbalna i niewerbalna przeplatają się i scalają w jedno wydarzenie komunikacyjne (Hecht, DeVito 1990, s. 4). Badacze — zwłaszcza antropolodzy kultury — niejednokrotnie „określając uwarunkowania sukcesu komunikacyjnego za granicą [...] brali pod uwagę to, że umiejętności niewerbalne są daleko bardziej istotne niż umiejętności werbalne" (Almaney, Alwan 1982, s. 18, cyt. za: Leathers 2007, s. 382). Również LaFrance i Mayo (1978) podkreślają, że niewerbalizmy zawierają wskazówki, reguły i nakazy co do akceptowanego zachowania w obrębie danej kultury (za: Leathers 2007, s. 382), co wiąże się z regułami grzeczności i standardami komunikacyjnymi. Co więcej, Singelis (1994, s. 275) zauważa, że znaczenie komunikatów niewerbalnych jest prawdopodobnie zdecydowanie większe podczas porozumiewania się osób z różnych niż tych samych kultur $^{3}$, a Gregersen (2007, s. 52) dodaje, że gestykulacja i mimika to istotne elementy strategii komunikacyjnej i duże źródło kompensacji w interakcji użytkowników L2 (języka drugiego).

Mimo istotności niewerbalizmów w komunikacji stosunkowo niewiele miejsca poświęca się roli komunikacji niewerbalnej w glottodydaktyce. Badaniem roli gestów w procesie nauczania i uczenia się języków obcych zajmowały się m.in. Jarząbek (1989), Allen (1999) i Gregersen (2007); o roli elementów paralingwalnych w edukacji pisał Pennycook (1985). O funkcji zachowań i komunikatów niewerbalnych ${ }^{4}$ nauczyciela podczas lekcji języka obcego wzmiankuje także Komorowska (2006). Puppel pisała o umiejętnościach niewerbalnych w kontekście nauki języków obcych (2001), o wpływie zachowań niewerbalnych na komunikację dydaktyczną (2002) i o bezpośredniości niewerbalnej nauczyciela języka obcego (2009). O komunikacji niewerbalnej w nauczaniu języka polskiego jako obcego, jak również o komunikacji niewerbalnej cudzoziemców uczących się ję-

3 ,The fact that at least one communicator is working in a second language means the verbal content may not be as clear as it would be in an intracultural interaction. Consequently, the reliance on nonverbal communication may be even greater than normal" (Singelis 1994, s. 275, cyt. za: Gregersen 2007, s. 52).

${ }^{4}$ Przy czym należy pamiętać, że zachowania niewerbalne nie są tożsame z niewerbalnym komunikowaniem się (por. Domachowski 1993, s. 14, 17). 
zyka polskiego, pisała Kubacka $(2011,2013)$. Zaledwie kilku badaczy wskazuje na rolę emblematów w glottodydaktyce: Azaoui (2013) badał emblematy nauczycielskie (classroom management emblems), a Luque Agulló (2014) udowodniła, że wprowadzenie m.in. emblematów do przekazywania wiedzy (np. podczas opowiadania jakiejś historii) zdecydowanie ułatwia zrozumienie przekazu przez uczniów.

Poniżej opisane badania mają charakter pilotażowy. Uczestniczyło w nich 30 osób uczących się języka angielskiego jedną z metod w ramach podejścia komunikacyjnego. Metoda INSELL (Interactional-Sequential Language Learning), czyli metoda interakcyjno-sekwencyjna, polega m.in. na stworzeniu (lub w miarę wiernym odtworzeniu) naturalnych sytuacji komunikacyjnych w sali lekcyjnej, jak również przedkłada nadrzędność komunikowania nad poprawność gramatyczną.

Średnia wieku badanych wynosiła ok. 25 lat. Najmłodszy uczestnik badań miał 15, najstarszy - ok. 60 lat, zdecydowana większość badanych była w wieku 20-25 lat. W badaniu wzięło udział 10 mężczyzn i 20 kobiet, jednakże kryterium płci nie było istotnym wyróżnikiem. Znajomość języka angielskiego uczestników badań oscylowała na granicy poziomu B2/C1 według CEFR (Common European Framework of Reference for Languages - Poziom biegłości językowej). Zakres kompetencji językowych/komunikacyjnych użytkowników języka na tym etapie jest następujący:

- osoba na poziomie B2 rozumie znaczenie głównych wątków przekazu zawartego w złożonych tekstach na tematy konkretne i abstrakcyjne. Potrafi porozumiewać się na tyle płynnie i spontanicznie, by prowadzić normalną rozmowę z rodzimym użytkownikiem danego języka, nie powodując przy tym napięcia u którejkolwiek ze stron. Potrafi formułować przejrzyste wypowiedzi ustne i pisemne w szerokim zakresie tematów, a także wyjaśniać swoje stanowisko w sprawach będących przedmiotem dyskusji, rozważając wady i zalety różnych rozwiązań.

- osoba na poziomie $\mathrm{C} 1$ rozumie szeroki zakres trudnych, dłuższych tekstów, dostrzegając także znaczenia ukryte, wyrażone pośrednio. Potrafi wypowiadać się płynnie, spontanicznie, bez większego trudu odnajdując właściwe sformułowania. Skutecznie i swobodnie potrafi posługiwać się językiem w kontaktach towarzyskich i społecznych, edukacyjnych bądź zawodowych. Potrafi formułować jasne, dobrze zbudowane, szczegółowe wypowiedzi dotyczące złożonych problemów, sprawnie i właściwie posługując się regułami organizacji wypowiedzi, łącznikami i wskaźnikami zespolenia tekstu ${ }^{5}$.

W świetle wcześniejszych rozważań oraz wyżej przytoczonych charakterystyk można zatem założyć, że od osób dobrze znających język angielski, a tym samym sprawnie posługujących się nim w rozmaitych sytuacjach komunikacyj-

5 Wyróżnienia A.S. 
nych, można i należy oczekiwać co najmniej dobrej znajomości znaków niewerbalnych typowych dla kultury brytyjskiej.

Aby to sprawdzić, wybrano 22 brytyjskie gesty emblematyczne o wysokim odsetku dekodowania (75-100\%). Gesty zebrano podczas badań przeprowadzonych w latach 2009-2011, przy użyciu zmodyfikowanej metody Johnsona, Ekmana i Friesena (1975) (zob. Szczepaniak 2011). Istotny jest fakt, że znaki kinetyczne typowe dla Brytyjczyków są w dużej mierze obce Polakom, nie są powszechnie znane i używane (przynajmniej nie świadomie i nie na dużą skalę). Jeśli Polacy znają te gesty lub używają ich, oznacza to, że najprawdopodobniej musieli się ich wcześniej nauczyć, zatem znaki te musiały być w jakiś sposób inkorporowane w proces glottodydaktyczny.

Wybrane gesty, typowe dla kultury brytyjskiej, mają różne nacechowanie emocjonalne oraz znaczenie. Rozpiętość aktów komunikacji jest spora — od okazywania życzliwości i radości, przez stwierdzanie, po obelgi i gesty obsceniczne, wulgarne. Znaczenie podanych gestów było następujące:

1: 'zwycięstwo'/‘pokój'/‘dwa'; 2: 'pieprz się'/‘spierdalaj’; 3: 'powodzenia'/ 'trzymam kciuki'; 4: 'pusta głowa'/‘to głupek'; 5: 'debil'/‘myśli penisem’ (dosł.); 6: 'o ja głupi'/‘ale głupiec ze mnie’; 7: 'pilnuj własnego nosa'/‘sekret'/‘niech to zostanie między nami'; 8: 'dupek'/‘fujara'; 9: 'mały penis’; 10: ‘żartuję'/‘ale ze mnie dowcipniś'; 11: 'seks oralny'; 12: 'pogarda'/'nie szanuję kogoś'; 13: ‘słowa, które wypowiadam, nie są prawdziwe'; 14: 'łapówka'; 15: 'to gej’; 16: 'mam potąd pracy'/‘jestem w tym po uszy'; 17: 'nie piję więcej alkoholu’; 18: 'słuszna uwaga'/'masz rację'/‘otóż to'; 19: 'obserwuję cię’; 20: 'punkt dla mnie'/‘mam lepszy argument'; 21: 'kłamstwa'/‘ktoś jest kłamcą’; 22: 'obiecuję'/‘przysięgam'.

W toku procedury badawczej pokazywano uczestnikom nagrania znaków kinetycznych o wyżej wymienionym znaczeniu. Rozdano również uczestnikom arkusze formatu A4, na których przedstawiono zdjęcia ilustrujące gesty w formie ponumerowanych miniatur (il. 1) - 18 gestów składających się z jednego ruchu (lub jego powtórzenia, przy zachowanym układzie dłoni i/lub gestu mimicznego, tzw. stroke ${ }^{6}$ ) oraz 4 gesty składające się z więcej niż jednego ruchu, zilustrowane sekwencją miniatur o różnej morfologii. Do zestawu zdjęć dołożono kartę odpowiedzi. Badani byli proszeni o odkodowanie gestów na obrazkach, czyli opisanie znaczenia danego gestu lub podanie słownego ekwiwalentu (np. nazwy emblematu lub frazy występującej zamiennie z gestem). Po zebraniu kart odpowiedzi podawano badanym prawidłowe znaczenie znaków, a podpisane arkusze z ilustracjami zostały zachowane przez badanych jako minisłowniki.

6 Polski odpowiednik tego terminu to „rdzeń ruchu”; fazy frazy gestykulacyjnej zdefiniował Kendon (1986). 

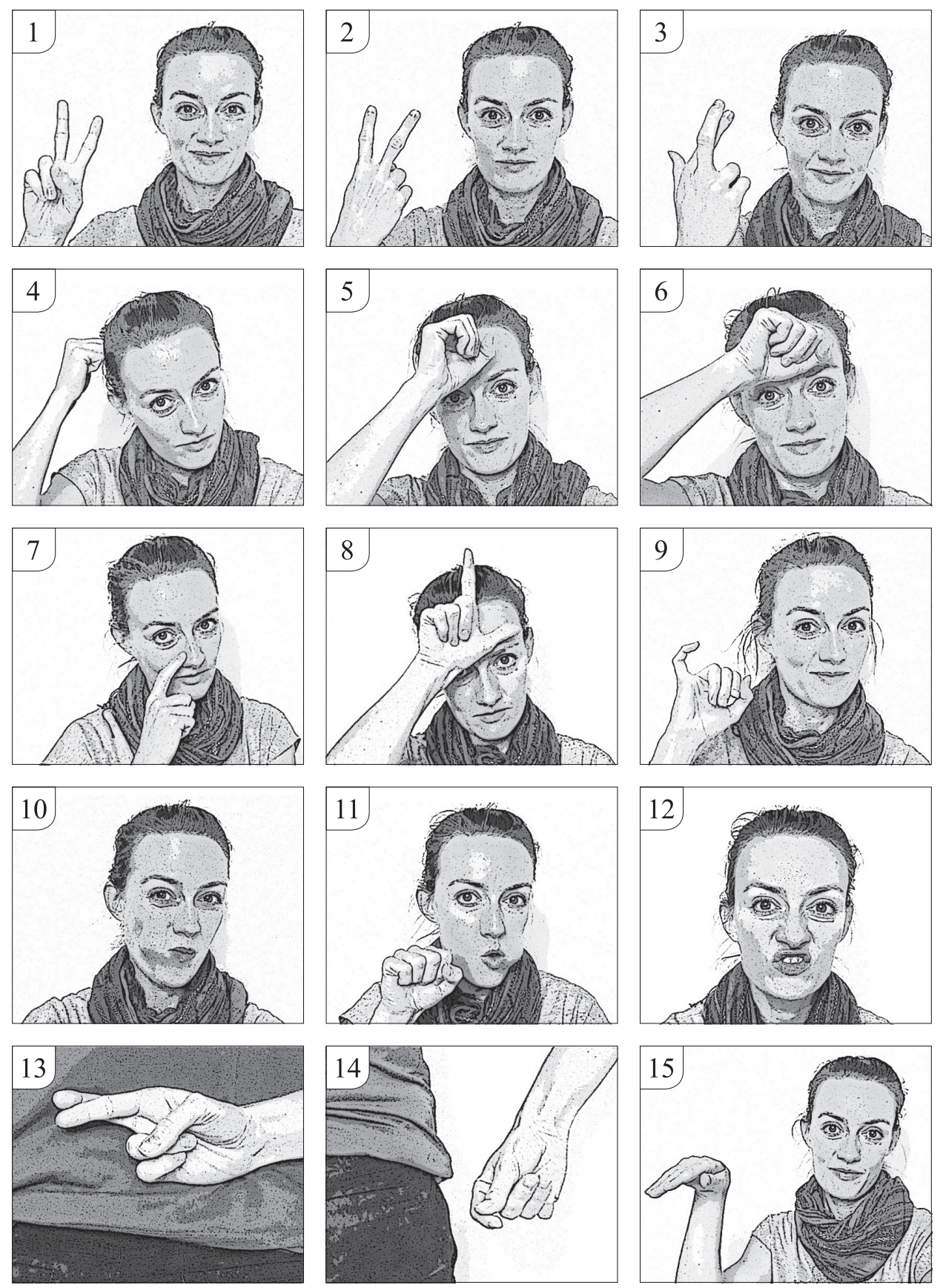

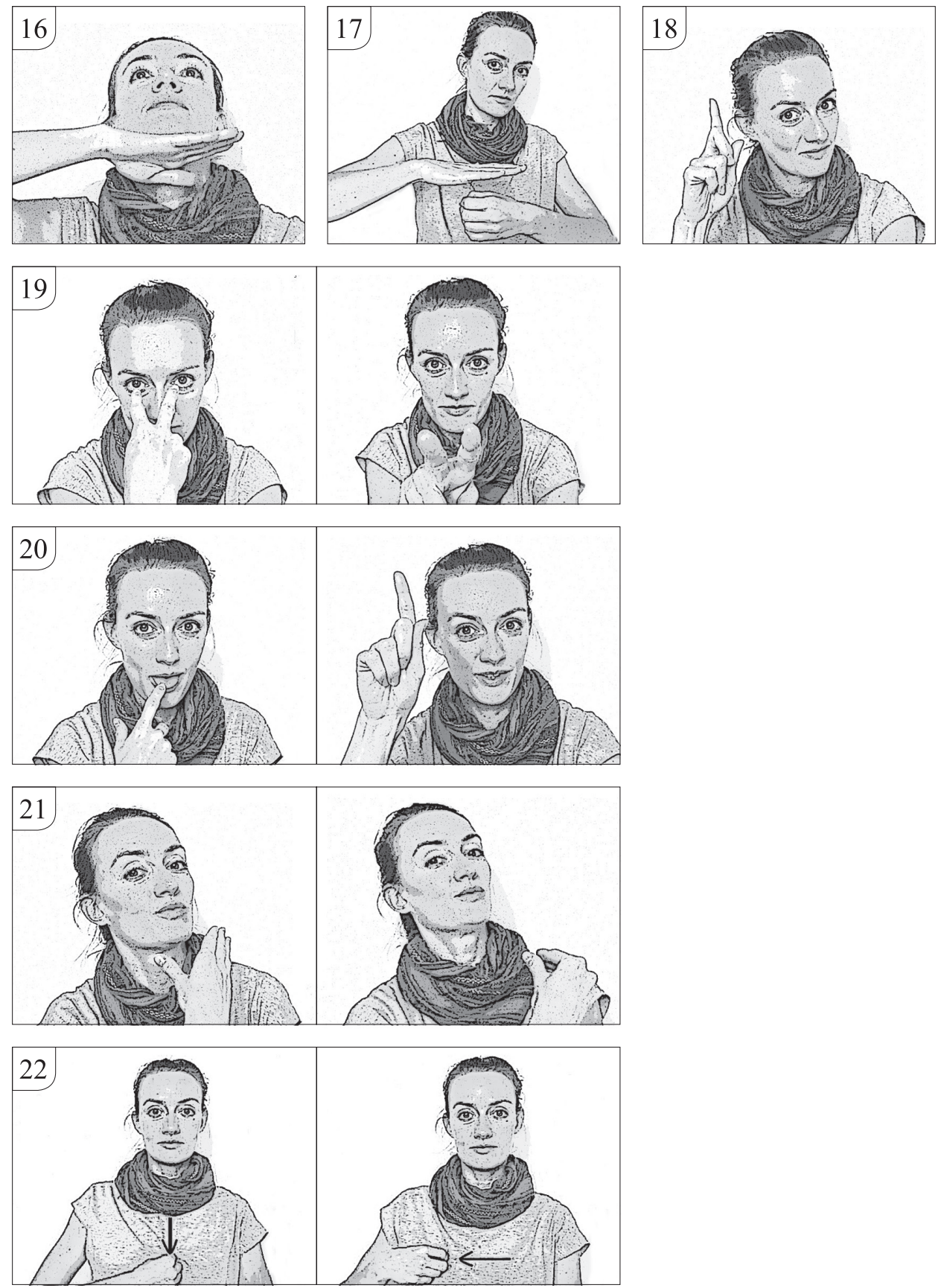

Rys. 1. Test znajomości brytyjskich gestów emblematycznych 
Odpowiedzi badanych zostały zebrane w tabeli. Drugi lub trzeci odsetek w ostatniej kolumnie znaczy, że badani odnosili się także do drugiego (lub kolejnego) znaczenia gestu. W przypadku, gdy jedna osoba udzieliła kilku poprawnych odpowiedzi, sumowano je; stąd też może wynikać ewentualna niezgodność między sumą poprawnych odpowiedzi a liczbą osób, które ich udzieliły. Fakt udzielenia odpowiedzi nie zawsze przekładał się na poprawność dekodowania. Niektóre odpowiedzi powtarzały się.

Tabela dekodowania gestów brytyjskich przez Polaków ${ }^{7}$

\begin{tabular}{|c|c|c|c|}
\hline $\begin{array}{l}\text { Numer } \\
\text { gestu }\end{array}$ & $\begin{array}{l}\text { Znaczenie podawane przez } \\
\text { ankietowanych }\end{array}$ & Znaczenie gestu & $\begin{array}{l}\text { Odsetek dekodowania } \\
\text { (poprawnych } \\
\text { odpowiedzi) }\end{array}$ \\
\hline 1 & $\begin{array}{l}\text { zwycięstwo; pokój; sukces; } \\
\text { odniosłem zwycięstwo; } \\
\text { powodzenia (enjoy); dwa } \\
\text { poproszę; w porządku!; OK }\end{array}$ & $\begin{array}{l}\text { 1. zwycięstwo/pokój } \\
\text { 2. dwa }\end{array}$ & $\begin{array}{l}\text { 1. } 26 / 30=87 \% \\
2.3 / 30=10 \% \\
(28 \text { osób odpowiedziało } \\
\text { poprawnie) }\end{array}$ \\
\hline 2 & $\begin{array}{l}\text { pieprz się; bardzo dobrze; } \\
\text { dwa; dwie szklanki wody/ } \\
\text { filiżanki kawy; chcesz } \\
\text { zamówić coś do picia?; } \\
\text { dwa piwa; obserwuję cię; } \\
\text { spierdalaj; patrz mi w oczy; } \\
\text { coś nieprzyjemnego; coś } \\
\text { obraźliwego }\end{array}$ & pieprz się/spierdalaj & $\begin{array}{l}10 / 30=33 \% \\
(10 \text { osób odpowiedziało } \\
\text { poprawnie) }\end{array}$ \\
\hline 3 & $\begin{array}{l}\text { życzenie powodzenia; może; } \\
\text { trzymać kciuki; tyle/a figa; } \\
\text { pocałuj mnie w dupę; żartuję; } \\
\text { kłamstwo; nic nie dostaniesz/ } \\
\text { zapomnij; nic; obiecuję }\end{array}$ & $\begin{array}{l}\text { powodzenia/trzymam } \\
\text { kciuki }\end{array}$ & $\begin{array}{l}10 / 30=33 \% \\
(10 \text { osób odpowiedziało } \\
\text { poprawnie) }\end{array}$ \\
\hline 4 & $\begin{array}{l}\text { ale z ciebie idiota; o mój } \\
\text { Boże; jesteś głupi; pomyśl; } \\
\text { obudź się!; zwariowałeś?; } \\
\text { staram się rozwiązać } \\
\text { problem; popukaj się - } \\
\text { głupi pomysł; myślę }\end{array}$ & $\begin{array}{l}\text { 1. pusta głowa/to głupek } \\
\text { 2. odpukać w niemalowane } \\
\text { (powodzenia) }\end{array}$ & $\begin{array}{l}\text { 1. } 18 / 30=60 \% \\
(18 \text { osób odpowiedziało } \\
\text { poprawnie) } \\
\text { 2. } 0 / 30=0 \\
\text { (nikt nie udzielił } \\
\text { poprawnej odpowiedzi) }\end{array}$ \\
\hline 5 & $\begin{array}{l}\text { jestem głupi; jesteś } \\
\text { jednorożcem; głupio się } \\
\text { czuję; czuje, że nie może } \\
\text { nic zrobić; głupi; fujara; } \\
\text { o tak, wiem; o cholera, co } \\
\text { narobiłem! }\end{array}$ & $\begin{array}{l}\text { kutas/debil/fajfus } \\
\text { (myśli penisem) }\end{array}$ & $\begin{array}{l}2 / 30=6 \% \\
(1 \text { osoba odpowiedziała } \\
\text { poprawnie, } 1 \text { osoba } \\
\text { podała podobne } \\
\text { znaczenie) }\end{array}$ \\
\hline
\end{tabular}

7 W tabeli zrezygnowano z podawania znaczenia w „łapkach” (“), a cudzysłowy (,”) pochodzą od badanych. 


\begin{tabular}{|c|c|c|c|}
\hline 6 & \begin{tabular}{|l|} 
ale ze mnie idiota; nie \\
rozumiem; jesteś głupi!; \\
tired; zapomniałem; głupi; o, \\
tak, faktycznie!; popełniłem \\
błąd; jestem zażenowany; \\
o mój Boże; zszokowany \\
lub zły z powodu czegoś \\
głupiego; jasne, kumam
\end{tabular} & $\begin{array}{l}\text { o ja głupi/ale głupiec ze } \\
\text { mnie }\end{array}$ & $\begin{array}{l}7 / 30=23 \% \\
(7 \text { osób odpowiedziało } \\
\text { poprawnie, } 5 \text { osób podało } \\
\text { podobne znaczenie, } \\
\text { łącznie } 40 \%)\end{array}$ \\
\hline 7 & $\begin{array}{l}\text { wiem coś; to mój interes; } \\
\text { o co chodzi?; mam pomysł; } \\
\text { czuję to; muszę pomyśleć; } \\
\text { serio?; nie wierzę; wpadnij na } \\
\text { to; rozumiemy się; narkotyki; } \\
\text { dłubie w nosie; lubisz } \\
\text { kokainę?; weź chusteczkę; } \\
\text { mądry; sekret; kłamię; leci } \\
\text { mi z nosa; coś śmierdzi }\end{array}$ & $\begin{array}{l}\text { 1. pilnuj własnego nosa } \\
\text { 2. niech to zostanie mię- } \\
\text { dzy nami/to sekret (ktoś } \\
\text { o czymś wie) } \\
\text { 3. ktoś o czymś wie/znam } \\
\text { jakąś tajemnicę }\end{array}$ & $\begin{array}{l}1.1 / 30=3 \% \\
\text { 2. } 1 / 30=3 \% \\
\text { 3. }(1 / 30=3 \%) \\
(3 \text { osoby odpowiedziały } \\
\text { poprawnie, tącznie } 10 \%)\end{array}$ \\
\hline 8 & $\begin{array}{l}\text { dupek, fujara; OK; kutas; } \\
\text { cienias }\end{array}$ & dupek/fujara & $\begin{array}{l}23 / 30=77 \% \\
(23 \text { osoby odpowiedziały } \\
\text { poprawnie })\end{array}$ \\
\hline 9 & $\begin{array}{l}\text { bzdury; mały facet; nie } \\
\text { wierzę ci; gest przysięgi; } \\
\text { obiecuję!; mam to w małym } \\
\text { palcu }\end{array}$ & mały penis/dupek & $\begin{array}{l}1 / 30=3 \% \\
(1 \text { osoba podała podobne } \\
\text { znaczenie })\end{array}$ \\
\hline 10 & $\begin{array}{l}\text { jestem najlepszy, świetnie } \\
\text { mi poszło; tak myślę; } \\
\text { zadowolenie z samego } \\
\text { siebie; frajerzy!; wrobili } \\
\text { mnie; stara się nie śmiać; } \\
\text { nie dbam o to; buńczuczny; } \\
\text { jestem w kłopocie; żartuję; } \\
\text { skupiony; robić loda; super; } \\
\text { zażenowanie }\end{array}$ & $\begin{array}{l}\text { 1. żartuję/ale ze mnie dow- } \\
\text { cipniś } \\
\text { 2. jestem niegrzeczny } \\
\text { 3. jestem świetny }\end{array}$ & $\begin{array}{l}1.2 / 30=6 \% \\
2.1 / 30=3 \% \\
3.3 / 30=10 \% \\
(6 \text { osób odpowiedziało } \\
\text { poprawnie, łącznie } 20 \%)\end{array}$ \\
\hline 11 & $\begin{array}{l}\text { obciągiwacz(ka); } \\
\text { popierdoleniec; seks oralny } \\
\text { z mężczyzną/możesz mi } \\
\text { obciągnąć; uprawiać seks; } \\
\text { pokazać komuś, że jest } \\
\text { ofiarą; czyścić zęby }\end{array}$ & $\begin{array}{l}\text { popierdoleniec/ osoba } \\
\text { uprawiająca seks oralny } \\
\text { z mężczyzną/ możesz mi } \\
\text { obciągnąć }\end{array}$ & $\begin{array}{l}10 / 30=33 \% \\
(10 \text { osób odpowiedziało } \\
\text { poprawnie })\end{array}$ \\
\hline 12 & $\begin{array}{l}\text { obrzydzenie/pogarda; dobra } \\
\text { robota; o cholera!; zła } \\
\text { odpowiedź; mam problem; } \\
\text { być w trudnej sytuacji; nie } \\
\text { być zadowolonym z wyniku; } \\
\text { całus; myśleć; podejmować } \\
\text { decyzję }\end{array}$ & pogarda/nie szanuję kogoś & $\begin{array}{l}1 / 30=3 \% \\
(1 \text { osoba odpowiedziała } \\
\text { poprawnie })\end{array}$ \\
\hline
\end{tabular}




\begin{tabular}{|c|c|c|c|}
\hline 13 & $\begin{array}{l}\text { kłamiesz i nie chcesz czegoś } \\
\text { zapeszyć; anulować coś } \\
\text { powiedziane wcześniej; } \\
\text { trzymać kciuki; mam } \\
\text { nadzieję, że przegrasz; } \\
\text { kłamię/kłamstwo; nie mówię } \\
\text { poważnie; nie dotrzymuje } \\
\text { obietnic; oszukuję; jestem } \\
\text { nieuczciwy }\end{array}$ & $\begin{array}{l}\text { kłamię/słowa, które } \\
\text { wypowiadam, nie są } \\
\text { prawdziwe }\end{array}$ & $\begin{array}{l}23 / 30=77 \% \\
(23 \text { osoby odpowiedziały } \\
\text { poprawnie) }\end{array}$ \\
\hline 14 & $\begin{array}{l}\text { sknera, dusigrosz; gratis; } \\
\text { pieniądze; potrzebuję } \\
\text { pieniędzy; łapówka; chcę } \\
\text { zapłacić }\end{array}$ & łapówka & $\begin{array}{l}1 / 30=3 \% \\
(1 \text { osoba odpowiedziała } \\
\text { poprawnie })\end{array}$ \\
\hline 15 & $\begin{array}{l}\text { jest fatalnie; } \\
\text { homoseksualista; zjeżdżaj; } \\
\text { daj mi spokój; idziesz na dno; } \\
\text { jesteś martwy; daj spokój; } \\
\text { jest ponad coś; jestem dobry; } \\
\text { zaniedbujemy kogoś; jesteś } \\
\text { spoko; nieważne; łatwizna; } \\
\text { jesteś gejem; cześć; smutna } \\
\text { surykatka; nie wierzę ci }\end{array}$ & homoseksualista/to gej & $\begin{array}{l}2 / 30=6 \% \\
(2 \text { osoby odpowiedziały } \\
\text { poprawnie) }\end{array}$ \\
\hline 16 & $\begin{array}{l}\text { mam tego potąd; mam } \\
\text { dość; mam mnóstwo pracy; } \\
\text { tonąć aż po szyję; głowa } \\
\text { w chmurach; jestem martwy; } \\
\text { zabić cię; za dużo; zginiesz }\end{array}$ & $\begin{array}{l}\text { 1. mam potąd pracy/jestem } \\
\text { w tym po uszy } \\
\text { 2. mam tego potąd }\end{array}$ & $\begin{array}{l}1.1 / 30=3 \% \\
\begin{array}{l}2.3 / 30=10 \% \\
(4 \text { osoby odpowiedziały } \\
\text { poprawnie, łącznie } 14 \%)\end{array}\end{array}$ \\
\hline 17 & $\begin{array}{l}\text { będzie dobrze; wystarczy; } \\
\text { mam cię; czas minął; } \\
\text { wystarczy mi (picie); nie } \\
\text { chcę pić; nie piję więcej; } \\
\text { czyste/czyścić; potrzebny mi } \\
\text { garnek }\end{array}$ & nie piję więcej alkoholu & $\begin{array}{l}5 / 30=17 \% \\
(3 \text { osoby odpowiedziały } \\
\text { poprawnie, } 2 \text { osoby } \\
\text { podały podobne } \\
\text { znaczenie) }\end{array}$ \\
\hline 18 & $\begin{array}{l}\text { tak, tak; myślę, że będzie } \\
\text { dobrze; dobry pomysł; } \\
\text { interesujące; właśnie/ } \\
\text { dokładnie tak; uważaj; mam } \\
\text { pomysł; mam cię; otóż to!; to } \\
\text { jest sedno sprawy; podkreślać } \\
\text { słowa; uwaga!; patrz na } \\
\text { mnie; wstydź się; poczekaj } \\
\text { chwilę; nie rób; mam świetny } \\
\text { pomysł }\end{array}$ & $\begin{array}{l}\text { słuszna uwaga/masz rację/ } \\
\text { otóż to }\end{array}$ & $\begin{array}{l}16 / 30=53 \% \\
(16 \text { osób odpowiedziało } \\
\text { poprawnie })\end{array}$ \\
\hline
\end{tabular}




\begin{tabular}{|c|c|c|c|}
\hline 19 & $\begin{array}{l}\text { obserwuję cię; nie sądzę; } \\
\text { mów prawdę - patrz mi } \\
\text { w oczy; patrz na mnie; widzę } \\
\text { cię; patrz mi (prosto) w oczy; } \\
\text { patrzę na ciebie/widzę cię; } \\
\text { będzie cię śledzić; mam na } \\
\text { ciebie oko; skup się; będę } \\
\text { cię obserwować; kontakt } \\
\text { wzrokowy }\end{array}$ & obserwuję cię & $\begin{array}{l}27 / 30=90 \% \\
(20 \text { osób odpowiedziało } \\
\text { poprawnie, } 7 \text { osób podało } \\
\text { podobne znaczenie) }\end{array}$ \\
\hline 20 & $\begin{array}{l}\text { jestem/jesteś gorący/-a; } \\
\text { powiedział coś mądrego; } \\
\text { obiecuję ci; mózg się gotuje } \\
\text { od ciężkiego myślenia; } \\
\text { gorąca dziewczyna; punkt } \\
\text { dla mnie!; gorąco!; myślimy } \\
\text { tak samo, zgadzamy się; } \\
\text { gdy ktoś mówi coś ostrego } \\
\text { o drugiej osobie; płoń; } \\
\text { ktoś gorący/atrakcyjny; } \\
\text { coś było tak świetne, że } \\
\text { trzeba to ochłodzić; zamknij } \\
\text { się; płonący żart; sexy- } \\
\text { gorąca/-y; coś jest gorące; } \\
\text { gadasz głupoty; gorąca } \\
\text { kobieta; miałem rację }\end{array}$ & $\begin{array}{l}\text { 1. punkt dla mnie/mam } \\
\text { lepszy argument } \\
\text { 2. gorąca dziewczyna/ je- } \\
\text { stem gorący/-a }\end{array}$ & $\begin{array}{l}\text { 1. } 3 / 30=10 \% \\
\text { 2. } 11 / 30=37 \% \\
(13 \text { osób odpowiedziało } \\
\text { poprawnie, łącznie } 43 \%)\end{array}$ \\
\hline 21 & $\begin{array}{l}\text { lubię brodę!; myśliciel; } \\
\text { jestem super; dowcip z brodą; } \\
\text { jestem najlepszy; niech } \\
\text { pomyślę; hm... interesujące; } \\
\text { myślę; cóż, udało się!; ktoś } \\
\text { się zastanawia i nie zna } \\
\text { odpowiedzi; ale bogacz; } \\
\text { ostrożnie rozważać; hmmm; } \\
\text { mądre rzeczy; podchwytliwe; } \\
\text { gentleman; ale jestem mądry }\end{array}$ & kłamstwa/ktoś jest kłamcą & $\begin{array}{l}0 / 30=0 \\
\text { (nikt nie udzielił } \\
\text { poprawnej odpowiedzi) }\end{array}$ \\
\hline 22 & $\begin{array}{l}\text { żegnanie się; wierzę; } \\
\text { spodziewać się śmierci; znak } \\
\text { religijny; Boże dopomóż; } \\
\text { wierzy, że Bóg dopomoże } \\
\text { mu w tej czynności; ktoś } \\
\text { jest zdenerwowany lub } \\
\text { zestresowany; obiecuję!; } \\
\text { modlitwa do Boga } \\
\text { przed czymś ważnym; } \\
\text { „chrześcijański znak”, np. } \\
\text { przed wejściem do kościoła }\end{array}$ & obiecuję/przysięgam & $\begin{array}{l}1 / 30=3 \% \\
(1 \text { osoba odpowiedziała } \\
\text { poprawnie) }\end{array}$ \\
\hline
\end{tabular}

Na podstawie analizy materiału można zauważyć, że stosunkowo niewielka część gestów brytyjskich jest poprawnie dekodowana przez badanych. Okazuje 
się, że najczęściej rozpoznawanym gestem (bo aż przez 90\% ankietowanych) jest znak 'obserwuję cię’ (ilustrujący przenoszenie wzroku z osoby na osobę). Drugim w kolejności najbardziej rozpoznawalnym znakiem jest gest zwycięstwa lub gestyczny symbol pokoju - poprawnie zinterpretowało go $87 \%$ badanych. Inne znaczenie tego gestu, liczebnik 'dwa', było jednakże znacznie mniej znane; tylko 3 osoby z 30 wskazały na nie. Wysoki odsetek dekodowania zanotowano w przypadku trzech gestów — znaku białego kłamstwa lub anulowania prawdziwości wypowiadanych słów (77\%), określenia kogoś mianem 'ofiary', 'loser' (77\%) oraz 'głupka' (60\%). Jedynym gestem rozumianym połowicznie przez ankietowanych (53\%) jest znak 'dobra myśl'. Odsetek dekodowania pozostałych znaków jest niższy niż 50\%; 11, czyli połowa gestów, zawiera się w przedziale $6-43 \%$, stopień rozumienia kolejnych 5 gestów nie przekracza $3 \%$.

Odnotowano 7 gestów o najniższym odsetku podanych odpowiedzi (niekoniecznie poprawnych): znak obietnicy/przysięgi oraz znak odmówienia alkoholu (po 10 odpowiedzi); znak pogardy (9 odpowiedzi); gest 'mam tego potąd'/'jestem zarobiony po uszy' oraz znak 'myśli penisem' (po 8 odpowiedzi); a także niepochlebne określenie czyjejś męskości oraz stwierdzenie, że ktoś ma preferencje homoseksualne (po 7 odpowiedzi). Fakt, że tak niewiele osób zdecydowało się udzielić odpowiedzi oraz że owe odpowiedzi nie zawsze były poprawne, może sugerować, iż badani nie znają tych gestów, a podane znaczenie jest domniemane. Najprawdopodobniej nie są to gesty dostępne Polakom; część tych gestów jest dość obraźliwa, zatem można przyjąć, że w napiętej sytuacji badani nie będą w stanie zrozumieć intencji nadawcy. Cztery spośród badanych gestów charakteryzuje bardzo niski odsetek dekodowania; znak obietnicy ('cross my heart'), łapówki, pogardy oraz określenia, że ktoś ma małego penisa, poprawnie odczytało zaledwie 3\% badanych. Najsłabiej dekodowany był gest kłamstwa ('chin chin') — na 21 odpowiedzi żadna nie była poprawna. W dużej mierze znak ten był mylnie rozumiany jako 'myśleć', przy czym nie jest to jedyny przypadek omyłkowego zinterpretowania gestu.

Tylko jedna osoba rozpoznała gest obietnicy czy przysięgi — reszta badanych zrozumiała go jako znak krzyża. Gest homoseksualizmu w dużej mierze był mylnie interpretowany jako machnięcie ręką; gest pogardy mylony był ze zniecierpliwionym cmoknięciem; pogardliwe określenie mężczyzny o małym penisie było rozumiane także jako gest obietnicy lub znakomitego opanowania jakiegoś zakresu wiedzy (przy czym - co ciekawe — taki gest w kulturze polskiej nie funkcjonuje; pokazanie małego palca łączy się raczej z frazą „tyle, co brudu za paznokciem”). Niewerbalne polecenie niewtrącania się w nie swoje sprawy ("pilnuj własnego nosa') bywało odczytywane jako gest nawiązujący do wciągania narkotyków lub do (nieprzyjemnego) zapachu. Uderzenie się w czoło na znak ukarania się za swoją głupotę było mylone z zażenowaniem lub przypomnieniem sobie czegoś. Życzenie powodzenia rozumiano m.in. jako ‘figa z makiem', kłamstwo lub „coś obelżywego". Podłożenie dłoni pod brodę na znak unoszenia się z trudnością na powierzchni, bycia zapracowanym, odczytywano jako groźbę podcięcia komuś gardła lub 
odniesienie do stanu zagrożenia życia. Obraźliwe polecenie natychmiastowego odejścia mylnie interpretowano jako 'dwa' lub polecenie patrzenia komuś w oczy. Wyśmianie głupoty dekodowano m.in. jako odwołanie do myślenia.

Ciekawe były również wybrane odpowiedzi ankietowanych dotyczące nieznanych im gestów. W takiej sytuacji badani najczęściej odwoływali się do ilustrującej warstwy gestu i podawali skojarzenia związane z danym znakiem. Stąd odpowiedzi typu ,potrzebny mi garnek”, ,jestem jednorożcem” czy „,smutna surykatka", przy czym wybrane frazy nierzadko mają charakter humorystyczny.

Ponadto w toku badań zaobserwowano, że stosunkowo niewielu ankietowanych wykazywało zainteresowanie gestami, a spora część uczestników wydawała się dość znudzona, choć fakt udzielenia poprawnej odpowiedzi budził z reguły spore ożywienie, podobnie jak rozpoznanie znanych gestów. Przeważała ogólna tendencja do traktowania zagadnienia jako ciekawostki, a nie przydatnej wiedzy kulturowej czy komunikacyjnej. Co więcej, okazało się, że niewiele osób planuje choćby krótki wyjazd do kraju anglojęzycznego w celu zwiedzania czy ćwiczenia porozumiewania się w rzeczywistych sytuacjach komunikacyjnych (ok. 5 osób z 30 badanych). Większość ankietowanych nie uczy się angielskiego, by się porozumiewać z Anglikami czy Brytyjczykami, tylko by znać język obcy w ogóle lub by móc porozumiewać się na gruncie międzynarodowym. Innymi słowy język angielski to dla większości badanych lingua franca, więc znajomość realiów kulturowych i skuteczne porozumiewanie się z rodzimymi użytkownikami języka wydają się im niepotrzebne.

Na podstawie powyższych rozważań można uznać, iż, w wyniku nieostrożnej gestykulacji lub lekceważenia roli gestów w komunikacji twarzą w twarz, badani Polacy obrażą Brytyjczyków, źle zrozumieją komunikat lub przekażą mylną wiadomość. Dla przykładu: zamawiając w pubie dwa piwa, mogą przekazać barmanowi obraźliwy komunikat. Pogardliwo-obraźliwy gest dotyczący homoseksualizmu mogą odebrać jako lekceważące machnięcie ręką lub odwrotnie - usztywniając nieco rękę w nadgarstku, chcąc machnąc ręką, obrażą rozmówcę, przekazując niepolityczną informację o jego domniemanych preferencjach seksualnych. Powoli wykonane cmoknięcie (z pokazaniem zębów) może zostać odebrane przez Brytyjczyków jako znak pogardy, lekceważenia. Innymi słowy — nawet niewinnie wyglądający gest może nieść z sobą duży ładunek emocjonalny oraz być obraźliwy.

$\mathrm{Z}$ badań wynika też, że sporo gestów obraźliwych charakteryzuje niski odsetek dekodowania. Jest to o tyle niefortunne, że niezrozumienie lub omyłkowe pokazanie tych sygnałów może doprowadzić nawet do zerwania komunikacji. Sytuacja, w której badani Polacy wypowiadają się płynną i niemal bezbłędną angielszczyzną, jednocześnie używając repertuaru polskich gestów emblematycznych (a jest to na porządku dziennym), może być przyczyną kontrowersji lub nieporozumień. Trudno bowiem przyjąć, że osoba biegle posługująca się danym językiem i sprawnie funkcjonująca $\mathrm{w}$ danej kulturze może nie znać tabu lub nie mieć świadomości wykonywania obraźliwych gestów, zwłaszcza że w wielu kulturach 
odsetek rozumienia gestów wulgarnych i obraźliwych oscyluje w granicy $100 \%$. Co prawda, nie zbadano reakcji Brytyjczyków na obraźliwe zachowania Polaków i vice versa, ale w wielu zaobserwowanych przypadkach użycia przez Polaków różnych gestów Brytyjczycy reagowali zaskoczeniem lub tłumionym oburzeniem i odprężali się dopiero po krótkiej chwili, gdy zdawali sobie sprawę z tego, że mają do czynienia $\mathrm{z}$ obcokrajowcem. $\mathrm{Z}$ drugiej strony Polacy reagują zażenowaniem, gdy poniewczasie dowiadują się, że w takiej czy innej sytuacji obrazili rozmówcę. Nierzadko bowiem (w trakcie badań, ale także podczas wcześniejszych rozmów i obserwacji) pojawiały się informacje ustne, z których wynikało, że dopiero po poznaniu znaczenia wybranych gestów Polacy przypominali sobie momenty, w których ich brytyjscy rozmówcy nieoczekiwanie zaczęli zachowywać się dziwnie i nieadekwatnie do sytuacji, nierzadko z rezerwą, co prowadziło do niezrozumienia i napięć między stronami.

Okazuje się również, że mimo dobrej i bardzo dobrej znajomości języka, kompetencje kulturowo-komunikacyjne badanej grupy są stosunkowo niskie. Niezależnie od tego, czy badani byli kiedykolwiek w Wielkiej Brytanii czy nie, ich zainteresowanie kulturą oraz znajomość jej realiów jest nikła. Zaledwie niecała jedna czwarta całokształtu podanych gestów ( 5 z 22) była poprawnie odczytana przez badanych Polaków. Połowa gestów była dekodowana przez mniej niż połowę ankietowanych (a w dużej mierze mało znana). Kolejne 23\% (5) gestów było praktycznie nierozpoznawalnych. Innymi słowy: zdecydowana większość, bo $75 \%$ badanego materiału, to znaki w sumie nieznane ankietowanym Polakom. Zdarzało się również przekładanie polskich znaczeń na brytyjskie znaki (np. skojarzenie gestu nawiązującego do małej męskości z frazą „mieć coś — jakąś wiedzę - w małym palcu"), co tym bardziej nie może ułatwiać ewentualnej komunikacji. Co prawda, badania miały charakter pilotażowy, a próba była niewielka, ale można ostrożnie założyć, że podobna tendencja będzie utrzymywała się także w przypadku szerszego grona Polaków uczących się angielskiego, co zdają się potwierdzać kolejne obserwacje.

W przypadku poprawnie interpretowanych gestów można założyć, że albo dobrze ilustrują czynność lub znaczenie, które chcą wyrazić, albo są na tyle powszechne, że rozpoznawalne (często widziane $\mathrm{np}$. w internecie, filmach czy telewizji). Znak 'obserwuję cię', ilustrujący przenoszenie wzroku z osoby na osobę, jest prawdopodobnie na tyle czytelny, że może być poprawnie dekodowany nawet przez osoby nieznające repertuaru gestów brytyjskich (aczkolwiek — jak zostało wyżej wykazane - pozorna oczywistość czy czytelność znaku może być bardzo myląca). Znak 'loser', nawiązujący do etykietki 'L' przyłożonej do czoła, co prawda nie powinien być poprawnie odczytany przez Polaków, ale najwidoczniej jest na tyle powszechny, że jego dekodowanie nie sprawia większego problemu.

Z badań można wysnuć ostrożny wniosek, że wciąż istnieje dość duża luka w ofercie programowej polskich szkół, zarówno publicznych, jak i prywatnych 
(także językowych). Zdaje się zasadne wprowadzenie do programu nauczania języków obcych - nie tylko angielskiego - zagadnienia komunikacji niewerbalnej w kontekście skutecznego porozumiewania się. Znajomość choćby podstawowego repertuaru gestów typowych dla danej kultury z pewnością przyczyni się do skuteczniejszego porozumiewania się/sukcesu komunikacyjnego, pozwoli uniknąc nieporozumień w procesie porozumiewania się, pozytywnie wpłynie na spostrzegawczość uczących się danego języka oraz ich wrażliwość na zjawiska kulturowe, jak również na ich świadomość językową i kulturową.

Dlatego też przyswajanie sobie gestów ściśle związanych ze studiowanym językiem wydaje się ze wszech miar pożyteczne i uzasadnione.

\section{Bibliografia}

Almaney A.J., Alwan A.J. (1982), Communicating with the Arabs: A Handbook for the Business Executive, Prospect Heights, IL.

Allen L.Q. (1999), Functions of nonverbal communication in teaching and learning a foreign language, „The French Review” 72 (3), s. 469-479.

Azaoui B. (2013), One teacher, two instructional contexts. Same teaching gestures?, „TiGeR: Tilburg Gesture Research Meeting", Tilburg, http://hal.archives-ouvertes.fr/hal-00833026 (dostęp: 21 sierpnia 2014).

Domachowski W. (1993), Psychologia społeczna komunikacji niewerbalnej, Toruń.

Efron D., (1941/1972), Gesture, Race and Culture, The Hague-Paris.

Ekman P. (1999), Emotional and conversational nonverbal signals, [w:] Gesture, Speech, and Sign, red. L.S. Messing, R. Campbell, New York, s. 45-55, http://dx.doi.org/10.1093/acprof:o so/9780198524519.003.0003 (opublikowano on-line w marcu 2012).

Ekman P., Friesen W. (1969), The repertoire of nonverbal behavior: Categories, origins, usage and coding, „Semiotica” 1, s. 49-98.

Gregersen T.S. (2007), Language learning beyond words: Incorporating body language into classroom activities, [w:] Reflections on English Language Teaching, red. T. Ruanni, F. Tupas, D. Xudong, S. Lopez-Nerney, M.L. Sadorra, Ch. Varaprasad, t. 6, nr 1, Singapore, s. 51-64, http://www.nus.edu.sg/celc/publications/reflections.htm.

Hansen K., Witkowska M. (2014), Obcokrajowcy i imigranci a język polski. Polacy a języki obce. Na podstawie Polskiego Sondażu Uprzedzeń 2013, http://cbu.psychologia.pl/uploads/f_winiewski/PPS2\%20raporty/Obcokrajowcy\%20a\%20jez\%20polski_raport_KH\&MaW.pdf (dostęp: 21 sierpnia 2014).

Hecht M.L., DeVito J.A. (1990), Perspectives on nonverbal communication: The how, what and why of nonverbal communication, [w:] The Nonverbal Communication Leader, red. J.A. DeVito, M.L. Hecht, Prospect Heights, IL, s. 3-17.

Jarząbek K. (1989), Znaki kinetyczne wspomagające komunikację mowna i ich miejsce w nauczaniu języków obcych, Katowice.

Johnson H.G., Ekman P., Friesen W.V. (1975), Communicative body movements: American emblems, „Semiotica” 15 (4), s. 335-353.

Kendon A. (1986), Current issues in the study of gesture, [w:] The Biological Foundation of Gestures, red. J.L. Nespoulous, P. Perron, A.R. Lecours, Hillsdale, s. 24-45.

Komorowska H. (2006), Metodyka nauczania języków obcych, Warszawa. 
Kubacka K. (2011), Komunikacja niewerbalna w nauczaniu języka polskiego jako obcego, [w:] Bogactwo językowe i kulturowe Europy w oczach Polaków i cudzoziemców, red. M. Biernacka, M. Wojenka-Karasek, Łódź, s. 132-139.

Kubacka K. (2013), Komunikacja niewerbalna cudzoziemców uczacych się języka polskiego jako obcego. Wyrażanie niepewności, watpliwości, niewiedzy lub niezrozumienia, [w:] Edukacja Międzykulturowa. Forum Glottodydaktyczne. Materiały z Konferencji Naukowej, red. A. Rabczuk, Warszawa, s. 426-437.

LaFrance M., Mayo C. (1978), Cultural aspects of nonverbal communication, „International Journal of Personality and Social Psychology" 38, s. 36-89.

Leathers D.G. (2007), Komunikacja niewerbalna. Zasady i zastosowania, Warszawa.

Luque Agulló G. (2014), Kinetics: A Forgotten 'Language'to Facilitate Comprehension and Intake of Narratives in Beginning Secondary English Classrooms, http://www4.ujaen.es/ gluque/Kinetics.pdf, (dostęp: 25 sierpnia 2014).

Pennycook A. (1985), Actions speak louder than words: Paralanguage, communication, and education, „TESOL Quarterly” 19 (2), s. 259-282.

Puppel J. (2001), Umiejętności niewerbalne w kontekście nauczania/uczenia się języków obcych, „Neofilolog” 19, s. 28-33.

Puppel J. (2002), Wpływ zachowań niewerbalnych na jakość i skuteczność komunikacji dydaktycznej, [w:] Autonomizacja w dydaktyce języków obcych: doskonalenie się w komunikacji ustnej, red. W. Wilczyńska, Poznań, s. 175-188.

Puppel J. (2009), Bezpośredniość niewerbalna a efektywność nauczyciela języka obcego, [w:] Wokót języka i kultury - studia interdyscyplinarne, red. W. Lankiewicz, Piła, s. 41-50.

Singelis T. (1994), Nonverbal communication in intercultural interactions, [w:] Improving Intercultural Interactions, red. R. Brislin, T. Yoshida, Sage, s. 268-294.

Szczepaniak A. (2011), Kulturowe i pozakulturowe aspekty komunikacji niewerbalnej na przykładzie gestów emblematycznych używanych w wybranych krajach Europy. Polsko-grecko-brytyjskie studium porównawcze, niepublikowana praca doktorska, Wrocław.

Szczepaniak A. (2012), Jak obrazić i przeprosić bez słów? Niewerbalne akty komunikacji w ujęciu kulturowym, „Język a Kultura” 23, red. A. Dąbrowska, A. Burzyńska-Kamieniecka, Wrocław, s. 471-485.

Szczepaniak A., Piekot T. (2009), Finding Kozakiewicz. In search of a method to identify Polish emblematic gestures, „GESPIN Post-conference” II (CD), Poznań.

\section{Źródła internetowe}

Poziom biegłości językowej CEFR: http://pl.wikipedia.org/wiki/Poziom_bieg\%C5\%82o\%C5\%9Bc i_j\%C4\%99zykowej (dostęp: 27 maja 2014).

Znajomość języków w Unii Europejskiej: http://languageknowledge.eu/countries/poland (dostęp: 31 sierpnia 2014). 


\section{A meeting of cultures, a meeting of gestures. On understanding selected British emblematic gestures by Poles learning English}

\section{Summary}

The text presents the results of research on decoding selected British emblematic gestures by Poles claiming a good command of English. Due to migration processes, as well as cultural rapprochement, Poles often find themselves in various communicative situations with people well versed in British culture. Understanding a repertoire of nonverbal signs is an indispensable factor of successful communication. In the text 22 typical British gestures mostly unknown and not used within Polish culture have been characterised, and the level of understanding of these gestures by Polish interlocutors has been estimated. The results of discrepancies between the meaning of the gestures and their decoding by Poles have also been presented.

Keywords: British emblematic gestures, decoding British emblems by Poles, nonverbal communication in glottodidactics, Polish-British nonverbal communication, successful intercultural communication, Poles learning English 